\title{
Softball Catching Learning Model Development for High School Students
}

\author{
Eva Faridah 1, Rubiyatno², Syahril Adam 3, Mikkey Anggara Suganda 4 \\ DOI: $10.35445 /$ alishlah.v13i3.808
}

Article Info

Key words:

Learning Model;

Softball Catching;

Hiah School Students;

PhysicalEducation
Kata kunci:

Model Pembelajaran;

Lempartangkap

softball;

Siswa SMA;

Pendidikanjasmani

Abstract

The study aims to create a softball throw and catch learning model for high school students. Based on the findings of observations and interviews, it is possible to conclude that students struggle with throwing and catching techniques on softball material. Physical education teachers face a challenge in providing appropriate learning methods due to a lack of variety in applying the learning model. The research and development (R \& D) method was used in this study, with six stages of development. The following data analysis techniques were used in this study: This study employs both quantitative and qualitative descriptive data analysis. Based on the findings of this study, ten throwing and catching learning models with various variations have been developed. The effectiveness test was performed with the T-test to determine the effectiveness of the developed product. The t-test value, tcount $=31,647$, was then obtained. The value of ttable obtained with confidence level $=0.05, \mathrm{dk}=(\mathrm{n}-1)=.30-1=30$ was 2.1098. As a result, tcount exceeds ttable (tcount $=31,647>$ ttable $=2,09.3$ ). Based on the test criteria of tcount $>$ ttable at $=0.05 \mathrm{dk}=17$, the developed model is very effective for use, particularly at the high school level.

\begin{abstract}
Abstrak
Penelitian ini bertujuan untuk mengembangkan model pembelajaran lempar tangkap softball pada siswa sekolah menengah atas. Berdasarkan hasil observasi dan wawancara dapat disimpulkan bahwa siswa masih banyak yang kesulitan dalam melakukan teknik lempar dan tangkap pada materi softball. Kurangnya variasi dalam menerapkan model pembelajaran menjadi tantangan tersendiri bagi guru penjas dalam memberikan metode pembelajaran yang tepat. Adapun metode penelitian vang digunakan dalam penelitian ini menggunakan metode resarch and development (R\&D) dengan menggunakan 6 tahapan pengembangan. Teknik analisis data yang digunakan dalam penelitian ini adalah analisis data deskriptif kuantitatif dan kualitatif. Berdasarkan hasil penelitian tersebut terdapat 10 model pembelajaran lempar tangkap vang dikembangkan dengan berbagai macam variasinya. Untuk melihat efektivitas produk vang dikembangkan dilakukan uii efektivitas dengan uii T. Kemudian diperoleh nilai uii-t diperoleh thitung $=31,647$. Nilai ttabel dengan taraf kepercavaan $=0,05, \mathrm{dk}$ $=(\mathrm{n}-1)=30-1=30$ diperoleh nilai sebesar 2,1098. Dengan demikian thitung lebih besar dari ttabel (thitung $=31,647>$ ttabel $=2,093$ ). Berdasarkan kriteria
\end{abstract}

\footnotetext{
${ }^{1}$ Un iv ersitas Negeri Medan, Indonesia

Em ail: ev afaridah@unimed.ac.id

2 Universitas Tanjungpura Pontianak, In donesia

Em ail: rubiyatno@fkip.untan.ac.id

3 ST KIP Kie Raha Ternate, In donesia

Em ail:syahril_adam@stkipkieraha.ac.id

4 Un iv ersitas Nahdlatul Ulama Cirebon, In donesia

Em ail: mikkey.anggara@yahoo.com
}

Vol.13(3) December, 2021

Received: July 16, 2021; Received in revised form: October 13, 2021; Accepted: October 15, 2021; Available on line: October 19 , 2021

This is an open access article under a Creative Com mons Attribution-NonCom mercial-ShareAlike 4.0 In ternational License 
pengujian bahwa jika thitung $>$ ttabel pada $\alpha=0,05 \mathrm{dk}=17$, model yang dikembangkan sangat efektif untuk diterapakan khususnya pada jenjang sekolah menengahatas.

\section{INTRODUCTION}

Physical education is a learning process through physical activity intended to improve physical fitness while also developing motor skills, knowledge, and behaviour related to healthy and active living, sportsmanship, and emotional intelligence. It is also known as physical activity education. The learning environment is meticulously controlled to encourage the growth and development of each student in all areas, including physical, psychomotor, cognitive, and affective development (Bangun, 2016). When it comes to physical education, it is a process that involves providing students with learning experiences that take the form of physical activities such as playing and exercising that are systematically planned to stimulate physical growth and development as well as motor skills and thinking skills as well as emotional, social, and moral growth and development. Ainin (2011) defines physical education as the essential part of the general education process, which comprises cognitive, affective, and psychomotor aspects, according to the opinion mentioned above. As a result, the process of implementing physical education at every level of education must be maximized. It is defined as a physical exercise that has been specifically organized to serve as a medium for educational activities. It indicates that physical activity can be used as a teaching tool to educate pupils on various topics, including cognitive, emotional, and psychomotor components.

According to the Ministry of National Education, the primary goal of physical education in schools is to help children improve their movement abilities while also being joyful and wanting to participate in various activities (Hendriana \& Jacobus, 2017). Cognitive comprehension and the beneficial nature of physical activity all contribute to developing a physically and intellectually fit human being with an upbeat personality. Researchers have conducted studies about physical education. Physical education contributes to future human growth and development (Rahmawati \& Huda, 2018). Physical education instruction in schools can be regarded as an endeavo ur to develop students' talents and interests within the school environment to maximize students' capacities. Not only that, regular physical education helps children feel fitter and prevents them from contracting numerous diseases. Physical fitness is critical for daily activities. However, the value of physical fitness varies according to the jobs or professions of each individual (Ramdhani, 2017). Physical education is so replete with diverse beliefs and experiences. Numerous factors contribute to pupils' ability to learn about emotion control. Multiple activities in physical education, such as games, dexterity, and skills, demand concentration and energy expenditure to achieve the highest performance (Aeni, 2014). This is what distinguishes physical education from other fields (Rohmah, 2016).

The softball game is one of the tools used to teach physical education in high school. Softball is a team sport that can be played by various age groups, including children and adults. Softball games are inextricably linked to defensive and offensive techniques and plans (Rihatno \& Gunawan, 2014). Softball's primary methods include hitting, catching, and throwing. Softball's objective is to win by scoring as many points as possible and completing all bases. Softball is a game that people of various ages and genders may play (Susworo, 2006). Softball is a sport played using a ball, a bat, a glove, and a field. Softball's fundamental movement techniques include throwing, catching, and batting. Through footwork, arm and hand movements took body movements. With the harmony of the entire series of activities, it can be concluded that these skills, namely a series of throwing, catching, and hitting movements, demonstrate the accuracy of displaying every detail of motion in each phase of the action (Nainggolan \& Manalu, 2020).) Softball is a game that can help students develop their motor abilities. Softball is a relatively simple sport to learn; because the fundamental techniques and motions required are few, pupils are only 
urged to throw, catch, hit, and run. This results in softball becoming a preferred material in classrooms, particularly at the high school education level (Pradana \& Nurrochmah, 2020).

High school students have specific developmental characteristics, and there are several of these characteristics can cause a teenager to experience anxiety. These characteristics include, among others, cognitive development, in which adolescents can imagine fictional situations and events that are only in the form of possible hypotheses or abstract proportions and process them with logical thinking at this stage (Sukur et al., 2020). It can cause anxiety in teenagers who have not been able to do so. Adolescent attachment to parents can serve an adaptive function by providing a secure base for adolescents to explore and master new environments and the larger social world in psychologically healthy psychological conditions (Hapsari et al., 2020). Parents can assist their children in dealing with the anxiety and potential feelings of tension or emotional tension that accompanies the transition from childhood to adulthood. Anxiety and a sense of being focused on teenagers will result from unsafe attachments with parents (Zainuri, 2020).

Based on observations and interviews with high school physical education teachers, there are several things that researchers are focusing on in the softball learning process in schools, namely the ability of students' throwing and catching techniques is still not optimal, there are often imperfect catches, and the ball sometimes escapes from the catch. As well as throws that are inaccurate or do not lead to the desired target, not to mention corrections in the delivery process that have not been packaged appealingly and have not encouraged students to move actively and enthusiastically to participate in the learning. So, the process of learning to throw and catch softball skills should be adjusted and modified according to the ability level of high school students and can be given with various variations of movement models and the use of learning media to achieve the desired goal. To improve students' ability to throw and catch softball, specifically by creating more varied and fun variations of the throwing and catching learning model to support the softball learning process This model is expected to increase students' motivation to participate in the learning process, particularly softball material, in the future. Several experts are also involved in the process of developing the model to assess or validate the learning model that is created in the hope that the quality of the developed model will be better and can be used by physical education teachers in particular.

\section{METHOD}

The development technique followed in this study is consistent with Borg \& Gall's development research procedures. Borg \& Gall (1983: 775) propose ten steps for conducting development research, which is then adapted into seven stages: (1) Field Data Collection, (2) Field Data Analysis, (3) Initial Product Development (Draft Model), (4) Expert Validation and Revision, (5) Small Scale Field Trial and Revision, (6) Large Scale Field Trial and Revision, and (7) Final Product Development. SMA 3 Pontianak and SMA 9 Pontianak were used as trial schools in this investigation. The following strategies were utilized to acquire data for this study: (a). Interviews are used to collect data when researchers want to perform a preliminary study to identify issues that need to be studied and when researchers want to learn more from respondents who are more in-depth. The sample size is small (Samsudin \& Rahman, 2016). The data gathering strategies employed are direct communication techniques with the aid of interview equipment. (b) Scale of evaluation The value scale is the second data collection instrument employed. This value scale is used to determine the viability of the throwing and catching learning model created before conducting small-scale trials (Rahim \& Taryatman, 2018). can be evaluated in small-scale clinical trials. The value scale classifies variables or study aims in-depth into symptoms and their components.

The descriptive data analysis technique was applied in this study. There are two types of data analysis techniques: quantitative and qualitative. Quantitative data analysis is used to analy ze data gathered from the observations of physical education experts and teachers regarding the 
quality of the draft model that was compiled and examined before the field trial's implementation (Yusuf \& Hartati, 2014). The second type of data analysis is qualitative data analysis. This type of analysis is conducted on data gathered from observations of physical education experts and teachers who provide suggestions or input and revisions to the model developed specifically for the field trial phase on both a small and large scale. (2019, Munajat) There are two values for the data gathered from material experts' observations of the throwing and catching learning model, the effectiveness of the throwing and catching learning model and the instructor experimenting. The result of the observation "yes" is one (1), but the result of the observation "no" is zero (0). The observation items' assessment findings are combined, and the resulting total value is transformed to determine the category. The conversion of values is performed by the Benchmark Reference Assessment (PAP) requirements.

\section{FINDINGS AND DISCUSSION}

The softball throwing and catching skill learning model's initial output consists of ten models created by researchers. Before testing, the researcher validated the initial product with specialists according to the findings of this investigation. The professionals engaged include a softball expert lecturer and a softball coach in Pontianak and physical education teachers who will use the product. Validation is accomplished by supplying an initial product draft or ten models created by researchers and evaluation sheets for specialists. The evaluation sheet is in the form of a questionnaire. It includes questions about the model's quality, suggestions, and comments from experts on the softball throwing skills learning product for high school students using teaching media.

Table 1. Expert validation data on the developed learning model

\begin{tabular}{|c|c|c|c|}
\hline No & Statement & Percentage & \\
\hline & & Yes & No \\
\hline 1 & Is this learning model fun? & 98,5 & 1,5 \\
\hline 2 & Is this learning model easy to understand? & 98 & 2 \\
\hline 3 & Is this learning model easy to do? & 97 & 3 \\
\hline 4 & $\begin{array}{l}\text { Can this learning model motivate students to throw } \\
\text { and catch the ball? }\end{array}$ & 97,5 & 2,5 \\
\hline 5 & $\begin{array}{l}\text { Can this learning model improve students' softball } \\
\text { throwing skills? }\end{array}$ & 100 & 0 \\
\hline 6 & Is this learning model safe to do? & 96 & 4 \\
\hline 7 & $\begin{array}{l}\text { Can this learning model train students' eye-hand } \\
\text { coordination? }\end{array}$ & 100 & o \\
\hline
\end{tabular}

The expert validation data in the table above shows that the developed learning model can motivate students in learning, is easy to use, fun, and safe. After this learning model was implemented, questionnaires were distributed to students to obtain data on student responses to this developed learning model. The following table is the data obtained from the questionnaire.

Table 2. Student responses after learning

\begin{tabular}{llcc}
\hline No & \multicolumn{1}{c}{ Statement } & Percentage & \\
\hline & & Yes & No \\
1 & Is this learning modelfun? & 99 & 1 \\
2 & Is this learning model not boring? & 98,5 & 1,5 \\
3 & Is this learning model easy to do? & 98 & 2 \\
4 & Does this learning model motivate you to follow the & 97,5 & 2,5 \\
& lesson? & & \\
5 & Does thislearning model exciteyou? & 96 & 0 \\
6 & Is this learning model safe foryou to do? & 100 & 0 \\
7 & Can this learning model improveyour focus? & 100 & 0 \\
\hline
\end{tabular}

The table above shows that most students stated that this learning model was fun and not dull. They also agree that this learning model can increase enthusiasm and make them motivated 
in learning. The following table presents data on testing the effectiveness of developing a complete learning model for catching softball.

Table 3. The test of catching softball model effectiveness

\begin{tabular}{|c|c|c|}
\hline Statistik & Pre-test & Post-test \\
\hline $\mathrm{N}$ & 30 & 30 \\
\hline Mean & 84,76 & 115,24 \\
\hline Median & 85,13 & 114,35 \\
\hline Mode & 64 & 95 \\
\hline Std. Deviation & 8,171 & 8,937 \\
\hline Varians & 66,773 & 79,867 \\
\hline Maximum Value & 99 & 129 \\
\hline Minimum Value & 64 & 95 \\
\hline
\end{tabular}

To determine the effectiveness of the learning model developed, the researcher tested the efficacy by experimenting by conducting a softball throw and catch test on 30 students before and after being given learning. The effectiveness test table above shows differences in the pretest and post-test data of the experimental group. It can be seen that the pretest mean data shows 84.76 and the post-test mean data shows 115.55, for the median pretest data shows 85,13 and 114.35 posttests, the maximum pretest value is 99, and the post-test maximum value is 129 .

Table 4. T-test

\begin{tabular}{lcccccc}
\hline \multicolumn{1}{c}{ Variabel } & $\mathbf{N}$ & Mean & $\mathbf{t}_{\text {tabel }}$ & $\mathbf{t}_{\text {hitung }}$ & Sig. & Keterangan \\
\hline Pretest & 30 & 84,76 & \multirow{2}{*}{1098} & 31,647 & 0,000 & Significant \\
Posttest & 30 & 115,24 & & & & \\
& & & & & \\
\hline
\end{tabular}

Based on the statistical test results of the variables, the t-test value was obtained, tcount $=$ 31,647 . The value of ttable with a confidence level $=0.05, \mathrm{dk}=(\mathrm{n}-1)=30-1=29$ obtained a value of 2.1098. Thus, tcount is greater than ttable (tcount $=31,647>$ ttable $=2,093$ ). Based on the test criteria that if tcount $>$ ttable at $=0.05 \mathrm{dk}=29$, it can be stated that the softball throwing and catching learning model is very effective in being used in the learning process of softball material in high school.

The study's findings indicate that developing the throw-and-catch learning paradigm in high school is an excellent method for improving softball throwing skills. This may be seen in the difference in average softball throwing skills between the experimental and control groups before and after using learning models and learning media. At the same time, the treatment group's average (115.24) was more significant than the control group's (84.76). These findings demonstrate that students' softball throwing skills can be improved by applying the proposed throwing and catching learning model. Teachers and students benefit significantly from the usage of teaching media as a tool for learning. By incorporating variations into the throwing-and-catching learning approach, children become bolder in their throwing and catching techniques. (Yudhi et al.,2018) found that employing media with actual ball alterations increased the ability to throw and catch baseballs by an average of 10.89 .

Every child's desire for movement activities must be satisfied to move around and discover new things while also channel their energy. The child's energy is also influenced by the child's very high movement needs, so if the energy is not conducted, the youngster may sense stress and anxiety and feel uneasy within himself. This is normal for children (Wicaksono, 2020). Softball learning is one of the physical activities included in the physical education curriculum, which provides a place for children to harness their movement demands.

Widiastuti et al. (2018) studied the development of the throwing-and-catching learning model for elementary school students. They found that it effectively improved student learning 
outcomes, as evidenced by statistical tests conducted before and after the model's implementation, which revealed significant differences in student learning outcomes.

According to Akbar's (2015) research, using manual-based softball throwing and catching game models makes it easier for students to grasp and adds additional information about the fundamentals of the sport. The results of the big and small group tests demonstrated that the construction of a softball learning game model based on a throw-and-catch approach met very high standards.

With various variations, softball throwing and catching learning motivate and engages students in physical education, particularly softball material. Students find it easier to grasp these fundamental techniques, and teachers benefit from the various models of throwing and catching variations that have been developed. The creation of this throwing and catching learning model is expected to benefit both the teaching and learning processes and increase students' interest and motivation to participate in softball learning (Irsyada et al., 2019).

\section{CONCLUSION}

These findings show that learning softball using learning media in high school is as many as ten applied models that can enhance and be practical to be used in the future. This research is still limited to being tested on a small sample. For further analy sis can be done on a larger sample. The results of this study are expected to be a reference for other researchers in developing learning models in physical education lessons.

\section{REFERENCES}

Aeni, A. N. (2014). Pendidikan Karakter Untuk Siswa Sd Dalam Perspektif Islam. Mimbar Sekolah Dasar. https://doi.org/10.17509/mimbar-sd.v1i1.863

Ainin, I. K. (2011). Strategi Pembelajaran Pendidikan Jasmani Adaptif. Jurnal Asesmen Dan Intervensi Anak Berkebutuhan Khusus.

Bangun, S. Y. (2016). Peran Pendidikan Jasmani Dan Olahraga Pada Lembaga Pendidikandi Indonesia. Publikasi Pendidikan. https://doi.org/10.26858/publikan.v6i3.2270

Hapsari, L. A., Astuti, A. P., \& Praswati, A. N. (2020). Konsumsi Makanan dan Olahraga selama Pandemi Covid 19. The 12th University Research Colloqium 2020 Universitas 'Aisyiyah Surakarta.

Hendriana, E. C., \& Jacobus, A. (2017). Implementasi pendidikan karakter di sekolah melalui keteladanan dan pembiasaan. Jpdi (Jurnal Pendidikan Dasar Indonesia). https://doi.org/10.26737/jpdi.v1i2.262

Irsyada, R., Rumini, R., \& Aji Putra, R. B. (2019). Metode Resiprokal Dalam Pembelajaran Hitting Permainan Softball. Media Ilmu Keolahragaan Indonesia, 8(2). https://doi.org/10.15294/miki.v8i2.17521

Munajat, I. (2019). Penggunaanpendekatan Bermain Beregu Untuk Meningkatkan Hasil Belajar Siswa Pada Pembelajaran Passing Bola Voli (Penelitian Tindakan Kelas di Kelas VIII-A SMP Negeri 4 tasikmalaya. Jurnal Wahana Pendidikan. https://doi.org/10.25157/wa.v6i1.2053

Nainggolan, A. P., \& Manalu, R. B. (2020). Modifikasi alat bantu pembelajaran melempar dan menangkap dalam hasil belajar permainan softball. Kinestetik, 4(1). https://doi.org/10.33369/jk.v4i1.10320

Pradana, A. A., \& Nurrochmah, S. (2020). Pengaruh Pembelajaran Metode Drill Terhadap Peningkkatan Hasil Belajar Lempar Bola Softball Kelas 7 Smp Negeri 1 Kota Malang. Gelanggang Pendidikan Jasmani Indonesia, 3(2). https://doi.org/10.17977/umo40v3i2p121129

Rahim, A., \& Taryatman. (2018). Pengembangan Model Pembelajaran Pendidikan Jasmani Adaptif bagi Anak Berkebutuhan Khusus di Sekolah Dasar Inklusif Kota Yogyakarta. Trihayu: Jurnal Pendidikan Ke-SD.An.

Rahmawati, A., \& Huda, A. (2018). Senam Pagi untuk Membangun Motivasi Belajar Siswa Tunagrahita.Jurnal Ortopedagogia. https://doi.org/10.17977/umo31v4i12018po26

Ramdhani, M. A. (2017). Lingkungan pendidikan dalam implementasi pendidikan karakter. Jurnal Pendidikan UNIGA. 
Rihatno, T., \& Gunawan, V. S. (2014). Efektifitas Pembelajaran Menggunakan Media Video Dan Media Cermin Terhadap Hasil Belajar Memukul Bola Softball. Jurnal Pendidikan Olahraga, 3(1).

Rohmah, N. (2016). Bermain Dan Pemanfaatannya Dalam Perkembangan Anak Usia Dini. Jurnal Tarbawi.

Samsudin, S., \& Rahman, H. A. (2016). Pengaruh metode pembelajaran drill, bermain, dan kelincahan terhadap kemampuan passing dalam permainan bola voli. Jurnal Keolahragaan. https://doi.org/10.21831/jk.v4i2.10899

Sukur, A., Amin, B. F., \& Arif, M. (2020). Edukasi Olahraga Dan Kesehatan Masyarakat Di Masa Pandemi Covid-19....Pengabdian Kepada Masyarakat.

Susworo, A. (2006). Acuan Pembelajaran Permainan Softball Model TGfU. Jurnal Pendidikan Jasmani Indonesia.

Wicaksono, A. (2020). Aktivitas Fisik Yang Aman Pada Masa Pandemi Covid-19. Jurnal Ilmu Keolahragaan Undiksha, 8.

Yusuf, W. B., \& Hartati, S. C. Y. (2014). Pengaruh Pemanasan Dalam Bentuk Permainan Terhadap Efektivitas Pembelajaran Pendidikan Jasmani, Olahraga dan Kesehatan. Jurnal Pendidikan Olahraga Dan Kesehatan.

Zainuri, K. (2020). Peningkatan Hasil Pembelajaran Lompat Jauh Melalui Pendekatan Bermain Longu Pada Siswa Kelas Iv Sdn 37 Ampenan. Jurnal Paedagogy. https://doi.org/10.33394/jp.v7i1.2513 